\author{
TUGAS JARINGAN KOMPUTER \\ "MODEL KOMUNIKASI DALAM ORGANISASI" \\ Robi Suganda \\ 175100001 \\ Universitas Mitra Indonesia, 175100001 \\ robisuganda.student@umitra.ac.id
}

\begin{abstract}
Abstrak
Komunikasi organisasi adalah pengiriman dan penerimaan berbagai pesan organisasi di dalam kelompok formal maupun informal dari suatu organisasi. Komunikasi formal adalah komunikasi yang disetujui oleh organisasi itu sendiri dan sifatnya berorientasi kepentingan organisasi. Isinya berupa cara kerja di dalam organisasi, produktivitas, dan berbagai pekerjaan yang harus dilakukan dalam organisasi. Misalnya: memo, kebijakan, pernyataan, jumpa pers, dan surat-surat resmi. Adapun komunikasi informal adalah komunikasi yang disetujui secara sosial. Orientasinya bukan pada organisasi, tetapi lebih kepada anggotanya secara individual.
\end{abstract}

\title{
A.CAPTURE PROGRAM
}

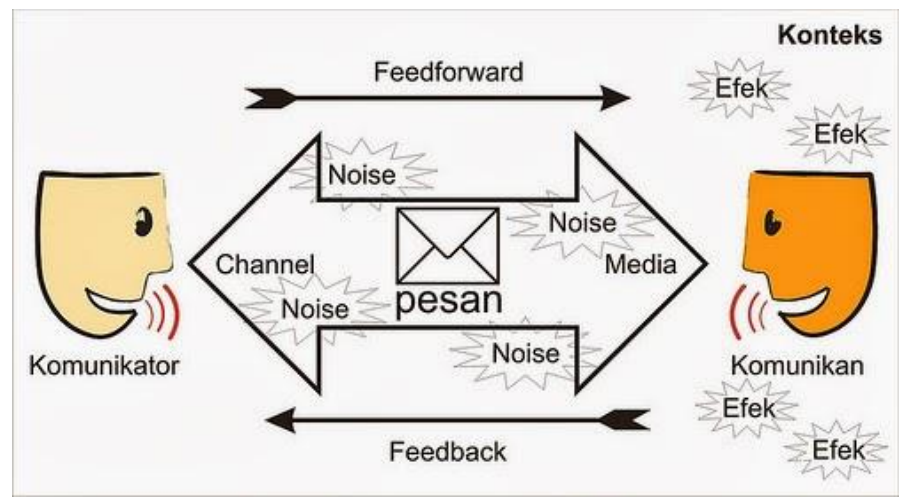

\section{B. PENJELASAN}

Organisasi dan komunikasi

Istilah organisasi berasal dari bahasa Latin organizare, yang secara harafiah berarti paduan dari bagian-bagian yang satu sama lainnya saling bergantung. Di antara para ahli ada yang menyebut paduan itu sistem, ada juga yang menamakannya sarana. 
1. Everet M.Rogers dalam bukunya Communication in Organization, mendefinisikan organisasi sebagai suatu sistem yang mapan dari mereka yang bekerja sama untuk mencapai tujuan bersama, melalui jenjang kepangkatan, dan pembagian tugas.

2. Robert Bonnington dalam buku Modern Business: A Systems Approach, mendefinisikan organisasi sebagai sarana dimana manajemen mengoordinasikan sumber bahan dan sumber daya manusia melalui pola struktur formal dari tugas-tugas dan wewenang.

3. Griffin (2003) dalam A First Look at Communication Theory, membahas komunikasi organisasi mengikuti teori management klasik, yang menempatkan suatu bayaran pada daya produksi, presisi, dan efisiensi.

\section{PENDEKATAN KULTUR/BUDAYA}

Dikemukakan oleh Michael Paconowsky dan Nock o'DonnelTrijullo yang memandang organiasasi sebagai suatu kultur, dalam arti bahwa komunikasi organisasi merupakan pandangan hidup (way of life) bagi para anggotanya. Menurut Pacanowsky dan Trujillo ada lima bentuk penampilan organisasi, yaitu:

a. Ritual yaitu merupakan bentuk penampilan yang diulang-ulang secara teratur, suatu aktuvutas yang dianggap oleh suatu kelompok sebagai sesuatu yang sudah biasa dan rutin. Ritual merupakan bentuk penampilan yang penting karena secara tetap akan memperbarui pemahaman kita mengenai pengalaman bersama dan memberikan legitimasi terhadap sesuatu yang kita pikirkan, rasakan dan kita lakukan.

b. Hasrat yaitu bagaimana para karyawan dapat mengubah pekerjaan-pekerjaan rutin dan membosankan menjadi menarik dan merangsang minat. Cara yang biasa digunakan adalah dengan penuturan pengalaman pribadi, rekan sekerja ataupun pengalaman yang diorganisasi ataupun perusahaan tempat ia bekerja.

c. Sosialitas yaitu bentuk penampilan yang memperkuat suatu pengertian bersama mengeni kebenaran ataupun norma-norma dan penggunaan aturan-aturan dalam organisasi, seperti kata susila dan sopan santun. Aspek lain dari sosialitas adalah 'privacy', yaitu penampilan sosialitas yang dikomunikasikan dengan penuh perasaan dan bersifat sangat pribadi seperti pengakuan, memberi nasihat dan penyampaian kritik.

d. Politik organisasi yaitu merupakan bentuk penampilan yang menciptakan dan memperkuat minat terhadap kekuasaan dan pengaruh, seperti memperlihatkan kakuatan diri, kekuatan untuk mengadakan proses tawar menawar (bargaining power) dan sebagainya.

e. Enkulturasi yaitu proses mengajarkan budaya kepada para anggota organisasi. Contoh bentuk penampilan ini adalah 'learning theropes' yang terdiri dari urut-urutan penampilan ketika orang mengajarkan kepada orang lain tentang bagaimana mengerjakan sesuatu. 


\section{PENDEKATAN HUMAN RELATION}

Pendekatan struktural dan fungsional mengenai organisasi dianggap hanya menekankan pada produktivitas dan penyelesaian tugas, sedangkan faktor manusia yang diabaikan. Menurut Chris Agrys, praktik organisasi yang demikian dipandang tidak manusiawi, karena penyelesaian suatu pekerjaan telah mengelahkan perkebangan individu dan keadaan ini berlangsung secara berulang. Ketika kompetensi teknis dinomorsatukan maka kompetensi antarpribadi dikurangi. Berdasarkan pemikiran itu maka pendekatan human realtions ini muncul.

Ada beberapa anggapan dasar dari pendekatan ini:

1) Produktivitas ditentukan oleh norma sosial, bukan psikologis.

2) Seluruh imbalan yang bersifat non ekonomis, sangat penting dalam memotivasi para karyawan.

3) Karyawan biasanya memberikan suatu reaksi persoalan, mengutamakan kelompok daripada individu.

4) Kepemimpinan memberikan peranan yang sangat penting dan mencakup aspek formal dan informal.

5) Komunikasi merupakan proses penting dalam pengambilan keputusan.

\section{DISKUSI}

Dari hasil diskusi di atas bahwa komunikasi organisasi adalah pengiriman dan penerimaan berbagai pesan organisasi di dalam kelompok formal maupun informal dari suatu organisasi dengan melakukan pendekatan human relation dan pendekatan kultur/budaya diantaranya:

1) Ritual

2) Hasrat

3) Sosial

4) Politik

5) dan Enkulturasi

6)

\section{D.REFRENSI}

[1] A. S. Putra And O. M. Febriani, "Knowledge Management

Online Application In Pdam

Lampung Province, " In Prosiding

International Conference On Information

Technology And Business(Icitb), 2018, Pp.181-187.

[2] A. S. Putra, O. M. Febriani,And

B. Bachry, "Implementasi Genetic

Fuzzy System Untuk Mengidentifikasi

Hasil Curian Kendaraan Bermotor Di

PoldaLampung,” J. Sist. Inf. Dan

Manaj. Basis Data, Vol. 1,

No.1, Pp. 21-30, 2018.
[3] O. M. Febriani And A. S. Putra, "Sistem Informasi Monitoring Inventori Barang Pada Balai Riset Standardisasi Industri Bandar Lampung, 'J. Inform., Vol. 13, No. 1, Pp. 90-98, 2014.

[4]Putra, Arie Setya. "2018 Artikel Struktur Data, Audit Dan Jaringan Komputer."(2018).

[5] Putra, A. S. (2018, July 17). Paperplain Fundamental Create Application With Borland Delphi 7.0 University Of Mitra Indonesia. Retrieved From Osf.Io/Pbrn9. 
